Open Access

\title{
Using Cultural Historical Activity Theory to understand how emerging technologies can mediate teaching and learning in a mathematics classroom: a review of literature
}

\author{
Marjorie Sarah Kabuye Batiibwe
}

$\overline{\text { Correspondence: batiibwemarjorie@ }}$ yahoo.co.uk; smbatiibwe@cees.mak. ac.ug

Department of Science, Technical and Vocational Education, School of Education, College of Education and External Studies, Makerere University, Kampala, Uganda

\begin{abstract}
The purpose of this paper was to review literature on the Cultural Historical Activity Theory (CHAT) and how it has been used to understand the mediation between emerging technologies and teaching and learning in a mathematics classroom. Specifically, it aimed at understanding the genesis of CHAT and further analyzing the studies that have employed CHAT as an analytical framework for teaching and learning in a mathematics classroom context. Two major concerns arise out of this review. Firstly, CHAT has been synonymously used with Activity Theory, leaving one wondering what actually the difference between the two in terms of researchers' conceptualization is. Secondly, although CHAT has been widely utilized in education research, scholarly articles that have employed it as their theoretical or analytical frameworks in a mathematics classroom context are still too few and yet still, the few that have utilized it have not exploited its maximum potential. The implications for this review for teachers in Uganda are active student engagement and creation of collaboration spaces for dialogue and interaction in the teaching and learning process.
\end{abstract}

Keywords: Cultural Historical Activity Theory, CHAT, Emerging technologies, Mathematics classroom, Mediation

\section{Description}

Cultural Historical Activity Theory (CHAT) provides an understanding of how technology can mediate teaching for transformational learning. This article reports on the genesis of CHAT and further analyzes the literature on the utilization of CHAT constructs in varying situations in a mathematics classroom. It identifies the gaps that arise from the literature before a conclusion is made.

\section{Introduction}

In the recent past, educators have changed their understanding of how learning should happen. For example, Mishra and Koehler (2006) argued that learning should include meaningful knowledge construction within the same context in which that knowledge

(c) The Author(s). 2019 Open Access This article is distributed under the terms of the Creative Commons Attribution 4.0 International License (http://creativecommons.org/licenses/by/4.0/), which permits unrestricted use, distribution, and reproduction in any medium, provided you give appropriate credit to the original author(s) and the source, provide a link to the Creative Commons license, and indicate if changes were made. 
will be used. Thus, knowledge and context cannot be separated, else knowledge risks being seen by students as a result of learning rather than a set of tools for solving problems in the teaching and learning process (Rowe, Bozalek, \& Frantz, 2013) which should engage the students in co-construction of knowledge. Siemens (2005) posits that learning is a process of creating connections and articulating a network with nodes and relationships, a concept he termed connectivist ideas. Similarly, according to Vygotsky (1978), social construction of knowledge depends on communicating gradual ideas through a described dialogue in which students learn how to think. One way of engaging students in a dialogue is through the use of emerging technologies (ETs). While Halawey (2013) suggests that technology is regarded as emerging if it is not widespread in a particular context such as place or application, Veletsianos (2016) defines ETs as tools, software, and concepts such as pedagogies that enable sharing instructional materials online. Examples of ETs are social media applications such as discussion fora, Google drive, and blogs (Brown \& Gachago, 2013).

ETs have the potential of bringing about transformative learning (Ng'ambi, Gachago, Ivala, Bozalek, \& Watters, 2014); enable learners to be engaged in new and interactive ways, with successful pedagogy (Sharples et al., 2016); support student engagement, creative thinking, collaboration, communication, and sharing of resources among students (Brown \& Gachago, 2013); and also provide meaningful platforms for social construction of knowledge (Veletsianos, 2011). However, while ETs are allocated these specific affordances, educators are still inclined to replicative traditional teaching practices (Ng'ambi et al., 2014) to the effect that they still use technology to deliver content, which in turn simply reinforces traditional teaching methods that have a limited impact on learning outcomes. How then can emerging technologies be used to mediate teaching for transformative learning? Drawing on the Cultural Historical Activity Theory (CHAT) through literature review, this article sought to understand how emerging technologies can mediate teaching in a mathematics classroom in order to realize transformative learning. The context in which this understanding was sought, the theoretical perspective of CHAT, and an analysis of the chosen literature, which was intended to look at how different scholars saw CHAT in their sites, what they found and the gaps are given in the subsequent sections of this article before a conclusion is made.

\section{Context}

The Uganda National Examinations Board (UNEB) syllabus argues that at an ordinary level ("O" level), "mathematics should be visualized as a vehicle for aiding a student to think, reason and articulate logically" (Uganda National Examinations Board, 2005, p.106). Thus, mathematics is seen as not only a subject capable to develop students' skills and reasoning that are required for productive citizens but also a key to understand other subjects. With UNEB's vision, mathematics remains compulsory for all primary and secondary students in the current curriculum framework in Uganda. However, it also remains one of the worst done subjects in both the Uganda Certificate Examinations (UCE) and Uganda Advanced Certificate Examinations (UACE) (Uganda National Examinations Board, 2012). In a bid to recuperate on the mathematics achievement by students in their UCE and UACE, the government of Uganda has set up several initiatives. For example, since 2012, Uganda has been retooling teachers and sensitizing head teachers in regard to ICT teaching and equipment usage and has set 
up over 1027 ICT laboratories in schools and district centers across the country. While it is well documented that ICTs have the added benefit of allowing learners to discover rules and generalizations for themselves (Naidoo, 2017), learners in Uganda are still far from satisfactory of such realism.

Although government initiatives are taking place, research on the ground (e.g., Batiibwe, Bakkabulindi, \& Mango, 2018) reveals that the use of ICT in institutions is still minimal and multiple challenges are faced. One of these challenges, of import to this analysis, is limited pedagogical skills among teachers with regard to effective ICT integration in teaching and learning, among others. Teachers, who are supposed to integrate ICT in their lessons, are simply trained in basic ICT skills and concepts without particular emphasis on ICT use for improving teaching and learning in specific subjects. The implication is that once teachers lack the subject-specific technological skills, they simply ignore the available technology and instead resort to their didactic teaching methods.

Then, the ICT tools are available with no good pedagogical use, yet Mishra and Koehler (2006) argued that intelligent pedagogical uses of technology require the development of a complex and situated form of knowledge which links technology to pedagogy and content. While there could be other reasons for low use of ICT in mathematics classrooms, as a mathematics teacher I suppose that for this particular context, it could be a pedagogical problem in the sense that ICT tools stand in isolation of teachers and students. Hence, there is a critical need to understand how teachers, students, and technology interact in order to transform teaching and learning, particularly in a mathematics classroom. This article utilizes CHAT to provide an understanding of how technology can mediate teaching in order to realize a transformation in learning during a mathematics classroom in Uganda.

\section{Methodology}

The search was conducted in three databases namely EBSCOHost, JSTOR, and Scopus that were accessed through the University of Cape Town online library between April and December 2018, and was limited to peer-reviewed articles that were published between 2007 and 2018. Broad search terms that included AT, Activity Theory, CHAT, Cultural Historical Activity Theory, Technology-Enhanced Learning, Mathematics Classrooms, and Mathematics were used with the aim of getting a more inclusive understanding of the theoretical underpinnings and the practical applications of CHAT in a mathematics classroom. The initial search yielded 91 references. However, the articles had to make an overt contribution at least to either of the following domains: understanding and/or advancing the generation of CHAT and its application to technology-enhanced learning in a mathematics classroom. Thus, all the 91 abstracts were screened, and in case of doubts, the article was kept for full-text screening.

Twenty-eight articles were excluded at this stage for the reason that they were theoretical papers. Thus, although the author had no full-text access to four articles, the remaining 59 empirical papers underwent full-text screening and, with the intention of ensuring that the scientific evidence presented in these suited the purpose of this review, a quality criterion according to Gough (2007) was employed. According to Gough, the research questions/purposes and data sources as well as the research questions and data analysis should be aligned; the research questions should be answered 
by the data; and the instruments for data collection, the data collection procedures, and the processes for data analysis should be discussed. Consequently, for an article to qualify for this review, there had to be an alignment between research questions/purpose, data analysis, discussion, findings, and CHAT. Still, 52 articles were excluded because they did not meet the quality criteria. Essentially, their authors just cited CHAT as a theoretical framework without a rich theoretical generation, and further, they neither applied it to the analysis, discussion, nor findings. This left only seven articles for indepth analysis for this review.

After presenting the evolution of CHAT, the author uses a spreadsheet to analyze the seven articles and to extract information about the nature and characteristics of each article in terms of context (the geographical location, purpose, and research questions), description (research method/design, participants, sample size and selection, data collection methods, data collection tools, and data analysis), and practical applications of CHAT in a mathematics classroom (mediating artifacts/tools, subject, object, outcome, rules, community, and division of labor). The findings from these studies as well as their discussion and their implications to teachers in Uganda are given, before a conclusion is made. The articles are summarized in the spreadsheets (Tables 1, 2, and 3). Finally, the author read again the analysis of the articles as presented in the spreadsheets to identify the specific contribution of these articles to the mathematics classroom. This resulted in the cross-article analysis presented in the review.

\section{Evolution of CHAT}

Activity Theory (AT) is more commonly known as Cultural Historical Activity Theory (CHAT). Its approach offers "... bridges between imagined, simulated and real situations that require personal engagement with material objects and artifacts (including other human beings) that follow the logic of an anticipated or designed future model of the activity" (Nussbaumer, 2012; Engeström, 2007, 37). The use of CHAT has dramatically increased in educational research over time due to the researchers' recognition of the importance of social aspects of learning. Historically, CHAT has gone through three generations where each builds upon the previous one. The generations are discussed below.

\section{First generation}

Vygotsky (1978) devised the concept of mediation, which is the first generation of AT. Basing on his studies of child development, Vygotsky argued that human beings as agents react to and act upon mediating objects of the environment such as tools, signs, and instruments leading to an outcome (Fig. 1) where, according to Engeström (2001), $\mathrm{S}$ is the stimulus, $\mathrm{R}$ the response, and $\mathrm{X}$ a complex and mediated act.

Leont'ev (1978) stretched afar the individual to a collective activity by integrating community and division of labor into Vygotsky's model, thus making it more of a systems approach. Although Leont'ev did not develop a graphical model, his work is presented as a hierarchical activity structure. This structure accounts for the historicalcultural traditions and experience as well as the cognitive rather than simply the physical process. As illustrated in Fig. 2, Leont'ev appended different levels, including 


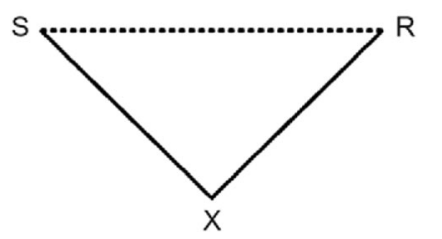

Subject

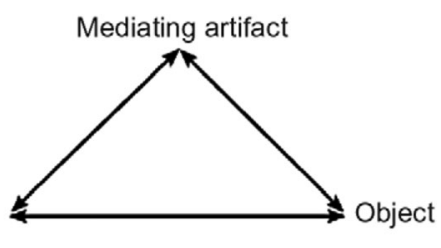

Fig. 1 First-generation CHAT (Engeström, 2001, p.134)

activity driven by motive, action guided by a conscious goal, and automatic operations influenced by conditions and tools (Nussbaumer, 2012).

\section{Second generation}

The second generation of AT is attributed to Engeström (1987). Vygotsky's earlier concept of mediation, which encompassed learning alongside others like Zone of Proximal Development (ZPD), and through interaction with artifacts, was the basis for Engeström's edition of AT. Engeström's approach was to explain human thought processes not simply on the basis of the individual, but in the wider context of the individual's interactions within the social world through artifacts, and specifically in situations where activities were being produced. He therefore incorporated the first generation of CHAT into his ideas by taking into account inter-relationships between the individual and the community, history, context, and interaction of the situation and activity (Fig. 3).

While the subject is the individual or groups of individuals involved in the activity, the object is the motivating influence behind subjects' participation in the activity. Mediating artifacts or tools are symbols, signs, and conceptual understandings that serve as physical and psychological tools, mediating activity between the subject and the object. A community is the social and cultural group that subjects are a part of, with explicit rules or social norms that regulate and influence behavior. The division of labor defines how tasks and responsibilities are shared among system participants as they engage in an activity (Cole \& Engeström, 1993). Thus, AT provides a conceptual

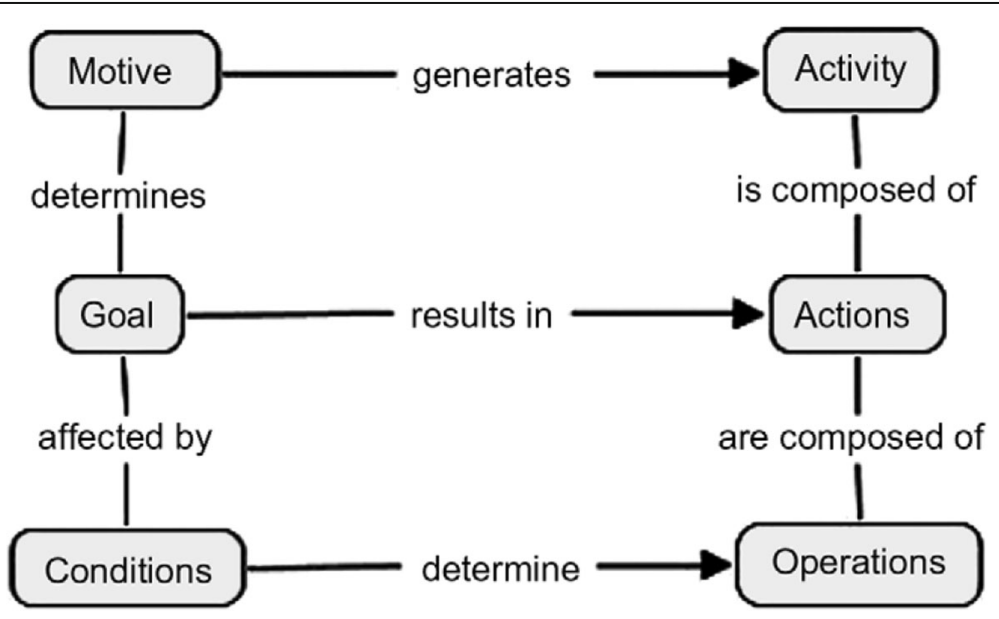

Fig. 2 Activity, actions, and operations (Nussbaumer, 2012) 


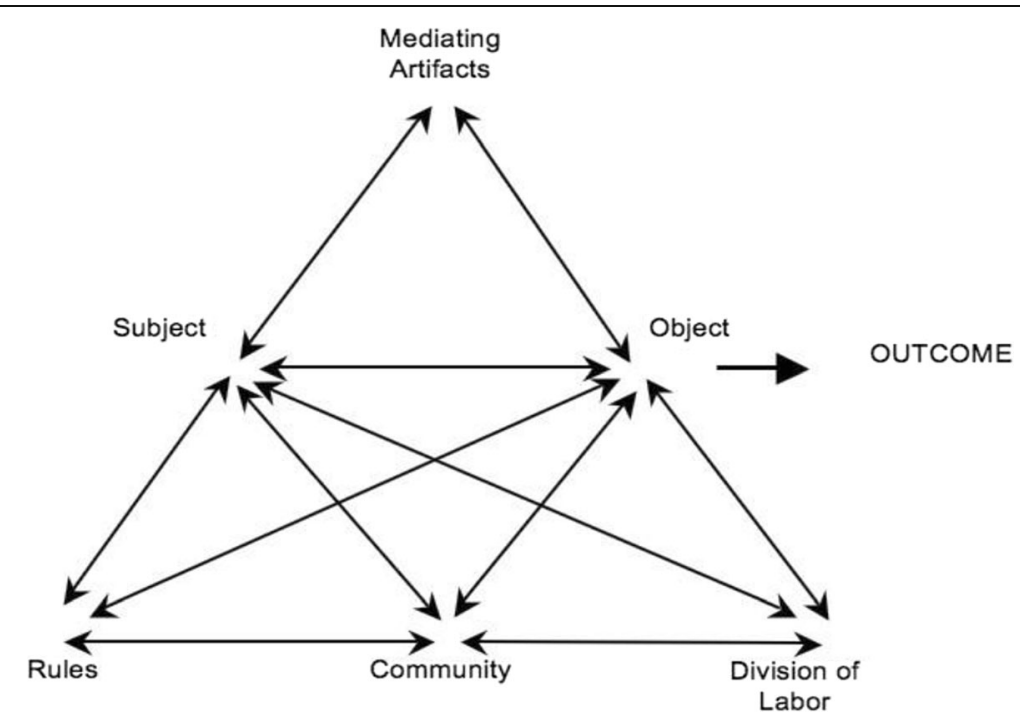

Fig. 3 Second-generation CHAT (Engeström, 1987)

framework from which one can understand the inter-relationships between activities, actions, operations and artifacts, subjects' motives and goals, and aspects of the social, organizational, and societal contexts within which these activities are framed.

\section{Third generation}

Engeström (2001) additionally specified activity systems to include networks of interacting systems to deal with tensions and contradictions that encourage collective learning through change, giving birth to the third generation of CHAT (Fig. 4). According to Roth (2007), “[e] ach individual act is based on Leont'ev's unity of activity, actions and operations" (p. 88), making the focal point a unity that can serve as the "minimum unit of analysis of productive human behavior" (p. 87). Whereas van Oers (2001) defines an activity in CHAT as "any motivated and object-oriented human enterprise, having its roots in cultural history, and depending for its actual occurrence on specific goal-oriented actions" (p. 712), Bakhurst (2007) defines an action as an activity that "can be portrayed as issuing from ... awareness of reasons" (p. 65). Meanwhile, environmental surroundings and past experiences influence the kinds of unconscious actions that are dependent upon conditions chosen by the subject to carry out

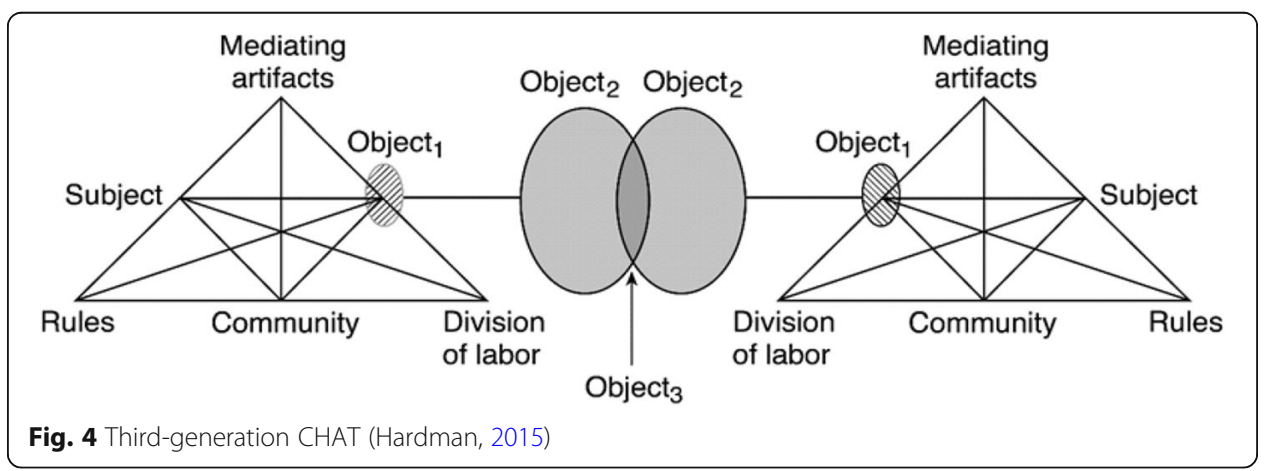


an activity. Operations are the mechanics of pursuing goals that describe what has to be done and are used to realize actions. Applying these explanations of activities, actions, and operations to teaching and learning enables the analysis of activity as the unit of analysis in CHAT.

\section{Analysis of literature}

\section{Context of the studies}

Table 1 shows that the reviewed studies used CHAT for varying purposes. For example, Beatty and Feldman (2012) viewed teacher transformation through the lens of CHAT and thus studied teacher change and pedagogical change as in-service secondary science and mathematics teachers learned Technology-Enhanced Formative Assessment (TEFA) in the context of a multi-year professional development program, termed Teacher Learning of TEFA (TLT). Their intention was to help the teachers to learn to use TLT successfully in their classes. Meanwhile, Hardman (2015) looked at the pedagogical variations with computers in South African mathematics classrooms through analyzing CHAT. CAMI, a drill and practice mathematics software, was her center of focus as being used in the lessons. Further, Hardman (2007) employed the AT approach to surface the pedagogical activity in primary mathematics classrooms in South Africa.

The focus of Hardman's (2007) study was on teachers rather than on students, and thus, Hardman investigated pedagogical practices by selecting object-oriented pedagogical activity as the unit of analysis. Regarding Huang and Lin (2013), they used the activity theory to model the Taiwan Atayal students' classroom mathematical activity. From the sociocultural perspective, they utilized the theory as the theoretical

Table 1 Contexts of the studies

\begin{tabular}{|c|c|c|c|}
\hline Authors & $\begin{array}{l}\text { Geographical } \\
\text { location }\end{array}$ & Purpose & Research question \\
\hline $\begin{array}{l}\text { Beatty and } \\
\text { Feldman } \\
(2012)\end{array}$ & Not specified & $\begin{array}{l}\text { Explore teachers' pedagogical change } \\
\text { through a professional development } \\
\text { assessment program }\end{array}$ & Not specified \\
\hline $\begin{array}{l}\text { Hardman } \\
(2015)\end{array}$ & South Africa & $\begin{array}{l}\text { Examining pedagogical variations } \\
\text { using a computer mathematics } \\
\text { software }\end{array}$ & $\begin{array}{l}\text { How does, and across what } \\
\text { dimensions, pedagogy potentially alter } \\
\text { with the introduction of computer } \\
\text { software into grade } 6 \text { mathematics } \\
\text { classes? }\end{array}$ \\
\hline $\begin{array}{l}\text { Hardman } \\
(2007)\end{array}$ & South Africa & Investigating pedagogy in a classroom & Not specified \\
\hline $\begin{array}{l}\text { Huang and } \\
\text { Lin (2013) }\end{array}$ & Taiwan & $\begin{array}{l}\text { Modeling a mathematics activity } \\
\text { (experiment) for teaching addition } \\
\text { and subtraction of integers }\end{array}$ & Not specified \\
\hline Naidoo (2017) & South Africa & $\begin{array}{l}\text { Explore the use of AT for the teaching } \\
\text { and learning of mathematics }\end{array}$ & Not specified \\
\hline Trust (2017) & USA & $\begin{array}{l}\text { Examine the network of sociocultural } \\
\text { factors in a professional development } \\
\text { network, Edmodo Math Subject } \\
\text { Community }\end{array}$ & $\begin{array}{l}\text { How is the process of seeking and } \\
\text { sharing knowledge shaped by the } \\
\text { sociocultural elements within a peer-to- } \\
\text { peer professional development } \\
\text { network? }\end{array}$ \\
\hline $\begin{array}{l}\text { Zevenbergen } \\
\text { and Lerman } \\
(2007)\end{array}$ & Australia & $\begin{array}{l}\text { Understand the tensions in the } \\
\text { practice of teaching with interactive } \\
\text { whiteboards }\end{array}$ & Not specified \\
\hline
\end{tabular}


framework to analyze the influences of cultural factors for Taiwanese Atayal junior high school students' study in mathematics, particularly, addition and subtraction of integers. While Naidoo (2017) aimed at exploring the use of activity theory as a framework for the teaching and learning of mathematics using visual tools, Trust (2017) used CHAT to examine the network of sociocultural factors in a professional development network (PDN) that mediate how teachers seek and share knowledge and, thus, he treated the Math Subject Community as an activity system.

Particularly, Trust (2017) employed the Edmodo Math Subject Community, a very popular PDN in the USA. In the meantime, Zevenbergen and Lerman (2007) were concerned with the ways in which interactive whiteboards (IWBs) were being used to support mathematical learning in the middle years of school in Australia. Precisely, they used the activity theory to understand pedagogical tensions in practice while teachers used IWBs. Although the studies have presented varying purposes, it can be noted from Table 1 that it is only Huang and Lin (2013) and Hardman (2007) who considered real mathematics content, namely addition and subtraction of integers and fractions respectively in their studies. The rest of the studies inclined to exploring programs like TEFA, Edmodo Math Subject Community, and CAMI math Software and tools like IWBs and visuals using CHAT, making them long-term studies. Furthermore, only two studies clearly stated their research questions.

In particular, while Hardman (2015) sought to address how, along which dimensions in an activity, pedagogy alters with the use of CAMI, a computer drill and practice software, Trust (2017) sought to deal with how the process of seeking and sharing knowledge shaped the sociocultural elements within a peer-to-peer professional development network. Although Beatty and Feldman (2012) did not specify the research questions of their study, they described TLT and teachers' classroom teaching as two linked activity systems. For TLT as an activity system, they considered the system to consist of the facilitators and participating teachers engaged in the activity of TLT. For the classroom as an activity system, Beatty and Feldman considered the system to consist of a secondary school teacher and his or her students, engaged in the activity of teaching a particular subject.

Besides, although Hardman (2015) clearly and theoretically explained an activity system, she did not actually specify what the activity system(s) in her context was/were. On their part, Huang and Lin (2013) viewed the activity system as being a unit of analysis, in which case it was the goal-oriented activity that they dealt with itself. In Naidoo's (2017) study, the activity system was the act of teaching and learning in mathematics classrooms. While Trust (2017) specified Math Subject Community as the activity system of his study, Hardman (2007) and Zevenbergen and Lerman (2007) did not define the activity systems of their studies.

\section{Description of the studies}

Table 2 reveals the studies' research methods/designs, the size of the participants, how they were selected, the data collection methods and tools, and finally how data were analyzed. Thus, Table 2 shows that only three studies revealed their research methods/ design. For example, Beatty and Feldman's (2012) employed a longitudinal, staggered site, delayed intervention design. While Hardman (2015) adopted a case study design in order to understand how teachers taught in the presence of computers and how or 
Table 2 Description of studies

\begin{tabular}{|c|c|c|c|c|c|c|}
\hline Author & $\begin{array}{l}\text { Research } \\
\text { method/ } \\
\text { design }\end{array}$ & Participants & $\begin{array}{l}\text { Sample } \\
\text { selection }\end{array}$ & Data collection methods & $\begin{array}{l}\text { Data } \\
\text { collection } \\
\text { tools }\end{array}$ & $\begin{array}{l}\text { Data } \\
\text { analysis }\end{array}$ \\
\hline $\begin{array}{l}\text { Beatty and } \\
\text { Feldman } \\
(2012)\end{array}$ & $\begin{array}{l}\text { Longitudinal, } \\
\text { staggered } \\
\text { site and } \\
\text { delayed } \\
\text { intervention }\end{array}$ & $\begin{array}{l}43 \text { in-service } \\
\text { science and } \\
\text { mathematics } \\
\text { teachers }\end{array}$ & $\begin{array}{l}\text { Not } \\
\text { specified }\end{array}$ & Not specified & $\begin{array}{l}\text { Not } \\
\text { specified }\end{array}$ & $\begin{array}{l}\text { Mixed- } \\
\text { methods } \\
\text { approach }\end{array}$ \\
\hline $\begin{array}{l}\text { Hardman } \\
(2015)\end{array}$ & Case study & 4 teachers & $\begin{array}{l}\text { Not } \\
\text { specified }\end{array}$ & $\begin{array}{l}\text { Demographic } \\
\text { questionnaire, interviews, } \\
\text { classroom observations, } \\
\text { video data of classroom } \\
\text { practice }\end{array}$ & $\begin{array}{l}\text { Not } \\
\text { specified }\end{array}$ & $\begin{array}{l}\text { Evaluative } \\
\text { episodes }\end{array}$ \\
\hline $\begin{array}{l}\text { Hardman } \\
(2007)\end{array}$ & $\begin{array}{l}\text { Exploratory } \\
\text { case study }\end{array}$ & $\begin{array}{l}4 \text { grade } 6 \\
\text { classes with } \\
153 \text { children } 4 \\
\text { grade } 6 \\
\text { mathematics } \\
\text { teachers }\end{array}$ & $\begin{array}{l}\text { Not } \\
\text { specified }\end{array}$ & $\begin{array}{l}\text { Detailed analyses of } \\
\text { teachers' teaching, } \\
\text { interviews with teachers } \\
\text { and students, classroom } \\
\text { observations of } 8 \text { lessons, } \\
\text { analysis of students' } \\
\text { productions }\end{array}$ & $\begin{array}{l}\text { Not } \\
\text { specified }\end{array}$ & $\begin{array}{l}\text { Evaluative } \\
\text { episodes }\end{array}$ \\
\hline $\begin{array}{l}\text { Huang and } \\
\text { Lin (2013) }\end{array}$ & Not specified & $\begin{array}{l}24 \text { grade } 7 \\
\text { Atayal students }\end{array}$ & $\begin{array}{l}\text { Not } \\
\text { specified }\end{array}$ & $\begin{array}{l}\text { Audio taping of } \\
\text { classroom teaching, } \\
\text { interviews, dictation of } \\
\text { videos, field notes, test } \\
\text { papers }\end{array}$ & $\begin{array}{l}\text { Not } \\
\text { specified }\end{array}$ & $\begin{array}{l}\text { Coding } \\
\text { through the } \\
\text { grounded } \\
\text { theory }\end{array}$ \\
\hline Naidoo (2017) & Not specified & $\begin{array}{l}6 \text { master } \\
\text { teachers }\end{array}$ & $\begin{array}{l}\text { Not } \\
\text { specified }\end{array}$ & $\begin{array}{l}\text { Master teacher } \\
\text { questionnaire, } \\
\text { observations of selected } \\
\text { lessons, field notes of } \\
\text { observations, individual } \\
\text { interviews with master } \\
\text { teachers, focus group } \\
\text { interviews with learners }\end{array}$ & $\begin{array}{l}\text { Not } \\
\text { specified }\end{array}$ & $\begin{array}{l}\text { Interpretive } \\
\text { paradigm }\end{array}$ \\
\hline Trust (2017) & Not specified & $\begin{array}{l}150 \text { (survey), } 10 \\
\text { (interview) }\end{array}$ & $\begin{array}{l}\text { Not } \\
\text { specified }\end{array}$ & $\begin{array}{l}\text { Online survey responses, } \\
\text { interviews, discussion } \\
\text { threads from Edmodo } \\
\text { Math Subject Community }\end{array}$ & $\begin{array}{l}\text { Not } \\
\text { specified }\end{array}$ & $\begin{array}{l}\text { Theoretical } \\
\text { thematic } \\
\text { analysis }\end{array}$ \\
\hline $\begin{array}{l}\text { Zevenbergen } \\
\text { and Lerman } \\
\text { (2007) }\end{array}$ & Not specified & 5 classrooms & $\begin{array}{l}\text { Not } \\
\text { specified }\end{array}$ & $\begin{array}{l}\text { Taking video of lessons, } \\
\text { interviews }\end{array}$ & $\begin{array}{l}\text { Not } \\
\text { specified }\end{array}$ & $\begin{array}{l}\text { Productive } \\
\text { pedagogies } \\
\text { framework }\end{array}$ \\
\hline
\end{tabular}

whether their pedagogy shifted across contexts, Hardman (2007) utilized an exploratory case study design in order to best investigate the pedagogical activity. It can also be noted that apart from Hardman's (2007) and Trust's (2017) studies, the rest of the studies involved very few participants, ranging from 4 to 43 . However, none of the studies specified how their participants were selected and why they were selected.

For example, Beatty and Feldman (2012) had 43 participating teachers from four sites, but they did not mention how they selected these teachers and the four cites from which they were as well as the country in which the study took place. Meanwhile, Hardman (2015) conducted her study in four disadvantaged grade 6 mathematics classrooms in the Western Cape Province of South Africa; thus, her study participants were four teachers from four Khanya project schools. The Khanya project in the Western Cape Province of South Africa was a government initiative involving a number of primary and secondary schools, which aimed to promote learning by integrating the use of appropriate technology, CAMI, a math software into the curriculum process. Hardman never revealed how neither the schools nor the teachers were selected and why. 
Additionally, Hardman's (2007) study sample comprised four previously disadvantaged primary schools in the Western Cape region of South Africa and, hence, four grade 6 classes with 153 children and four grade 6 mathematics teachers participated in the study. Still, the selection process of these was left to the author. While Huang and Lin (2013) collected data from 24 seventh grade Atayal students in Taiwan, Naidoo's (2017) study participants comprised of six master teachers from six different secondary schools located in KwaZulu-Natal (KZN), South Africa. However, both authors, too, did not reveal the participant selection process. Meanwhile, with anonymous participant selection procedures, Trust (2017) had 160 participants from the Edmodo Math Subject Community who participated in his study and 600 initial wall posts and 1908 replies to the posts. In the meantime, Zevenbergen and Lerman's (2007) study involved two schools, one in Queensland and another in Victoria in Australia, which were using IWBs. Across these schools, five classrooms were using IWBs.

Further, Table 2 reveals a number of data collection methods used in the studies, of which the most dominant were interviews, classroom observations, and audio/video recording classroom teaching/practices. Although all the studies gave their data collection methods, none of them gave details of the data collection tools. Conversely, when it came to data analysis, it was not so clear how the researchers analyzed their data. Mostly, they either made mention of general terms of analysis which were even not well elaborated or analyzed a part of them, despite variations in collection. For instance, Beatty and Feldman (2012) collected data from four sites in a span of one baseline semester and 2 to 3 years of professional development. Having collected data on the participants' backgrounds, outlooks, experiences, and classroom practice of TEFA through multiple instruments and methods, they left the instruments and methods unidentified. Moreover, in their article, they also made a general statement that they conducted their analysis by means of a mixed-methods approach and that the approaches were inclined more to qualitative than quantitative, leaving the readers in suspense.

Another case in point is Hardman (2015) who used various methods to collect data namely demographic questionnaires, interviews, classroom observations, and video data of classroom practice. However, she reported only on the video data gathered over the period of 1 year. Besides, while Hardman (2007) collected data through detailed analyses of teachers' teaching, interviews with teachers and students, and classroom observations and analysis of students' productions such as workbook or board work and further video-recorded eight lessons which served as the primary observational data set, she only examined the video data for evidence of evaluative episodes and disruptions in the pedagogical script where the teacher made visible the evaluative criteria required for students to produce a legitimate text. Of interest in the context of emerging technologies, Trust (2017) collected three sets of data through online survey responses, interviews, and discussion threads from the Edmodo Math Subject Community.

On part of data analysis still, all the studies employed interpretive approaches such as evaluative episodes, coding, and thematic analysis and by way of productive pedagogies framework. For example, for her analysis, first, Hardman (2015) developed a sampling mechanism capable of selecting evaluative episodes in the data that highlighted the object of the activity. Once episodes were identified, she coded the teacher and student talk in these evaluative episodes and then designed a CHAT coding schedule to analyze 
each episode she identified as a whole by assigning numerical values to tool use, rules, object, and division of labor on a four-point Likert-type scale. Trust (2017) conducted a theoretical thematic analysis of the survey data in order to identify the sociocultural contexts that influenced how teachers found and shared knowledge in the Math Subject Community. He further used the CHAT framework to generate initial codes using an Excel spreadsheet and then examined the dialectical relationships among the codes in order to gain a broader understanding of the complexity of the Math Subject Community activity systems.

\section{Application of CHAT in the mathematics classroom}

In line with the quality criteria by Gough (2007), each article for this review was inspected to look that it clearly identified the constructs of CHAT within its activity system. The summary of the findings can be found in Table 3 and is presented in what follows, construct by construct.

\section{Subject}

According to Cole and Engeström (1993), the subject is the individual or groups of individuals involved in the activity. Table 3 reveals that for all the studies, subjects were identified. Within the CHAT activity triangle, Beatty and Feldman (2012) and Hardman (2015; 2007) identified the individual teacher as their subject while for Huang and Lin (2013), the subjects of the activity system were the Atayal students, the teacher, and their actions and operations during the teaching/learning process. It can be discerned that whereas Atayal students are individuals, the teacher's actions and operations during the teaching/learning process are not.

To situate the activity theory model within the context of Naidoo's (2017) study, he defined the master teachers as the subject. According to him, a master teacher was an expert teacher as identified by the KwaZulu-Natal (KZN) Department of Education, experienced, and with the potential to mentor new teachers. Meanwhile, in the lens of activity theory, the subject in Trust's (2017) study were individuals interested in finding or sharing mathematics education knowledge such as teachers, higher education faculty, teacher educators, and anyone interested in exchanging professional knowledge related to mathematics education. For Zevenbergen and Lerman (2007), they were not clear about the subjects in their study.

\section{Object}

Cole and Engeström (1993) defined the object as the motivating influence behind subjects' participation in the activity. From Table 3, the teacher's instructional practice and the set of students were the objects in Beatty and Feldman's (2012) study. Although the set of students were mentioned as a motivating influence behind the teachers' pedagogical change, the authors never explained how they influenced the change as objects. However, it should be noted that at least TEFA had changing roles. For instance, TEFA was first introduced into classrooms as an object of activity and then made useful as a tool for instruction. The object of the activity in both Hardman's (2015) and Huang and Lin (2013) studies was the teaching and learning of mathematics. Meanwhile, that for Hardman (2007) was understanding fractions. Naidoo's (2017) study object was the 


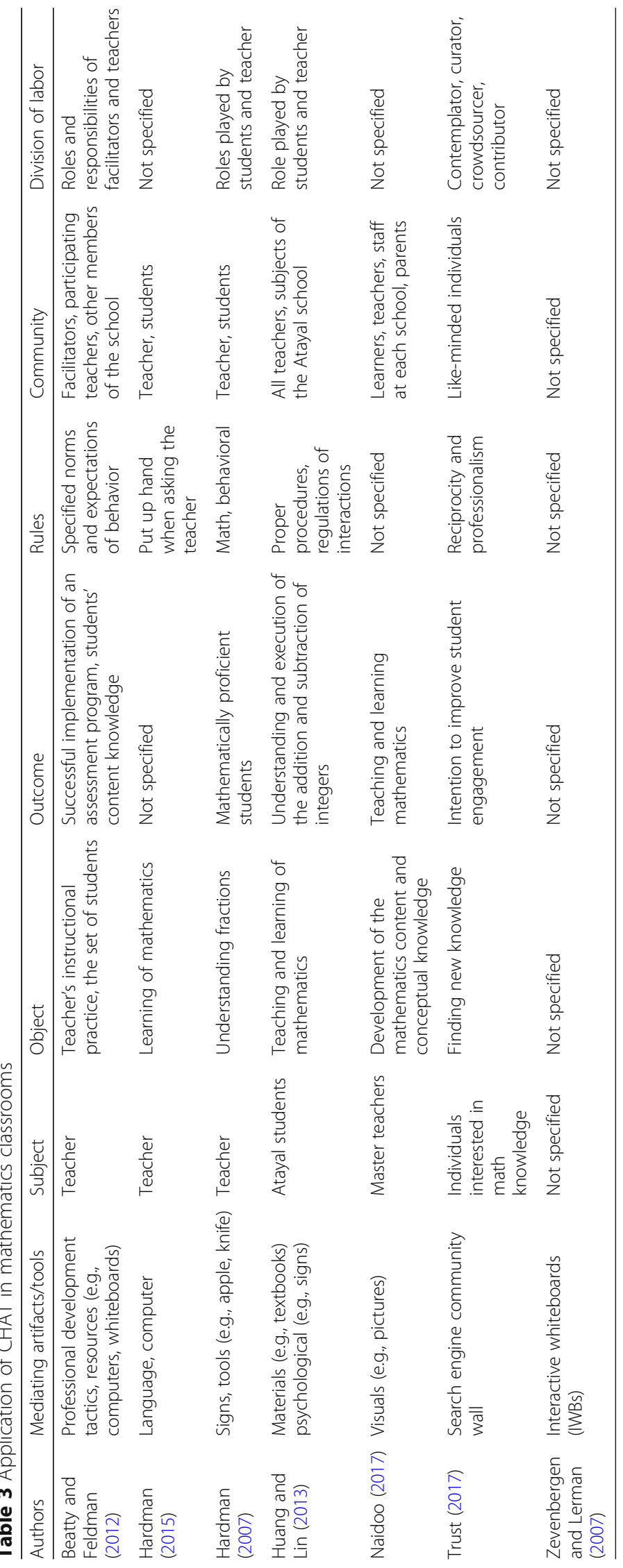


development of the mathematics content and conceptual knowledge while that for Trust (2017) was finding new knowledge. In the lens of activity theory, Zevenbergen and Lerman (2007) were not clear about the object. Thus, almost all the studies identified the object within the CHAT lens.

\section{Outcome}

In Beatty and Feldman's (2012) study, the successful implementation of TEFA to help students learn was the desired objective (outcome) as well as the students' content knowledge that was the raw material for producing the desired outcomes of the subject comprehension and readiness for standardized tests and subsequent schooling. While Hardman (2015) did not specify the outcome, Hardman's (2007) outcome was mathematically proficient students. Huang and Lin (2013) had their object outcome as understanding and execution of the addition and subtraction of integers, the results of the teaching/ learning activities. Meanwhile, for Naidoo (2017), the outcome was the teaching and learning of mathematics. Trust's (2017) outcome was the intention to improve student engagement in a professional development network, whereas Zevenbergen and Lerman (2007) were not specific about their study outcome.

\section{Community}

A community is the social and cultural group that subjects are a part of, with explicit rules or social norms that regulate and influence behavior (Cole \& Engeström, 1993). Table 3 reveals that the community as described by majority of the reviewed studies majorly comprised teachers and students, as a minimum. For instance, the collection of facilitators and participating teachers was the community in Beatty and Feldman's (2012) study. At least for them, in addition, their community also included other members of the school, such as support staff, counselors, administrators with disciplinary roles, and student teachers. In both Hardman (2015; 2007), the community included only the teacher and the students.

Huang and Lin (2013) defined the community as being all the teachers and subjects of the Atayal School. The community in Naidoo's (2017) study was the learners within the mathematics classroom, the teachers, the staff at each school involved in the study, and the parents within the community. Meanwhile, Trust's (2017) community consisted of like-minded individuals with the same goals and values. The Math Subject Community consisted of a large, diverse group of individuals who had a shared vision or purpose. On the other hand, Zevenbergen and Lerman (2007) were not able to identify their community clearly.

\section{Artifacts/tools}

Mediating artifacts or tools are symbols, signs, and conceptual understandings that serve as physical and psychological tools, mediating activity between the subject and the object (Cole \& Engeström, 1993). Table 3 reveals a variety of artifacts used in the different studies. For example, the tools of the system in Beatty and Feldman's (2012) study included the many different professional development tactics and resources employed to help teachers reflect upon their practice and improve their skills. These were a wide array of teaching and learning resources, ranging from concrete items like 
whiteboards, computers, and textbooks to abstract patterns of action such as activity types, teachers' questioning strategies, and recourses for disciplinary action. Meanwhile, Hardman's (2015) tools were the language and the computer in a context where there were different roles.

For Hardman (2007), the mediating artifacts/instruments were signs and tools like a knife, apple, blackboard, and instructional talk in mathematics. Huang and Lin (2013) defined their tools as representational tools, including material tools (textbooks and handouts) and psychological tools (language and signs). Meanwhile, Naidoo (2017) defined his mediating artifacts/instruments as visual tools that were used to teach mathematics. These visual tools included pictures, charts, manipulatives, technology, chalkboard, gestures, diagrams, and color. Each learning community in his study used their own symbols and visual tools to make mathematics more accessible to members within the learning community. The tools in Trust's (2017) study included the search engine that allowed members to search the entire Edmodo site and the community wall, a virtual space for posting questions and sharing resources. For Zevenbergen and Lerman (2007), the IWBs were the artifacts that shaped the ways in which learning occurred. The use of a variety of artifacts could be interpreted as the researchers' creativity in designing useful instruments that enhance the teaching and learning of mathematics.

\section{Division of labor}

The division of labor defines how tasks and responsibilities are shared among system participants as they engage in the activity (Cole \& Engeström, 1993). From Table 3, it is clear that almost all the studies had division of labor catered for. But was the division clearly articulated? Looking at Beatty and Feldman's (2012) division of labor, they specified the roles and responsibilities of the facilitators and teachers. Thus, the distribution of labor in the classroom specified the power structure, including the teacher's authority to designate learning goals for students, select and design learning activities, establish performance criteria and measures, and dictate behavior standards. However, for Hardman (2015), the division of labor was not well elaborated in terms of CHAT. In part, this could be for the reason that her focus was on pedagogical variations and that also, as there were four different teachers, she could have found it challenging to explicitly specify which teacher did what, given that they each came from different schools with varying backgrounds and contexts.

In Hardman (2007), both the teacher and the students had a role to play where the teacher's role was the mediator and the student's role the respondent. Although Huang and Lin (2013) defined the division of labor as the roles teachers and students played, they were not clearly articulated. Although in text, Naidoo (2017) expressed that the topic that master teachers handled was transformation geometry, the division of labor was not specific to this context. Thus, it is not easy to believe that division of labor can be general for all the six teachers, and more to it, each from a different school. By virtue of every classroom being an activity system, it is evidence enough that each activity system is special and unique wherein, the division of labor should be clearly spelt out. Trust's (2017) division of labor was among contemplators, curators, crowdsourcers, and contributors because participants brought a wide range of knowledge and 
experiences to the Math Subject Community. However, knowledge and experience varied depending on profession, experience, grade, among others. Although they mentioned the division of labor later in their article, Zevenbergen and Lerman (2007) never defined it, at least in their context.

\section{Rules}

For Beatty and Feldman (2012), the rules, explicit and implicit, and varying among teachers and classes, specified norms and expectations for behavior. Although in the CHAT diagram (Beatty \& Feldman, 2012, p. 292) they expressed rules as expectations and norms, they did not specify them in context as they did for the rest of the elements of the system. According to them, the rules element of the system was a source of tension, as many teachers felt that they were obligated to use TEFA. Hardman (2015) set up rules which afforded and constrained behavior, such as the rule to put up one's hand when asking the teacher a question. For Hardman (2007), there were rules to follow in this activity system namely the math rule and the behavioral rule. The math rule was to the effect that the denominator told how many parts a whole was divided into and the behavioral rule was to implicitly manage behavior through praise as well as instructional setting to manage behavior.

Huang and Lin (2013) referred to rules as the proper procedures and the regulations of interactions that were acceptable by the subjects and therefore had cultural properties, but they did not actually specify them. Further, although in text Naidoo expressed that the topic that master teachers handled was transformation geometry, his rules were not specific to this context. Rather, they were written in a more general form. Thus, since every classroom acts as an activity system, it is enough to know that each activity system is special and unique wherein rules should be clearly spelt out; in consequence, it is not convincing for Naidoo's study that the same rules generally worked for all the six teachers from six different schools. Meanwhile, Trust's (2017) rules were reciprocity (giving back to the Math Subject Community) and professionalism (being positive, respectful, and helpful). In contrast, Zevenbergen and Lerman (2007) did not specify the rules for their activity system.

\section{Results from the reviewed studies}

A CHAT analysis by Beatty and Feldman (2012) suggested that the primary contradiction within secondary education is a dual view of students as objects of instruction and willful individuals. Thus, the difficulties that arose from this contradiction either inhibited or motivated TEFA adoption. On her part, Hardman (2015) identified 28 evaluative episodes across $22 \mathrm{~h}$ of teaching time. She analyzed these episodes using the CHAT coding schedule from which she identified four ideal pedagogical types of tool use, rules, community, object, division of labor, and outcomes. These pedagogical types were reinforcement pedagogy, which had the reinforcement of specialized knowledge as its object; collaborative pedagogy, which had the development of metacognitive engagement with specialized knowledge as its object; directive pedagogy, which had the development of technical task skills as its object; and finally, defensive pedagogy, which had student regulation as its object. She further found that face-to-face lessons were 
characterized as predominantly reinforcement and collaborative pedagogy and most computer lessons were characterized as mainly either defensive or directive.

Having developed a methodology for using activity theory to investigate pedagogical practices in primary school mathematics classrooms by selecting object-oriented pedagogical activity as the unit of analysis, Hardman (2007) developed the notion of evaluative episodes as pedagogical moments in which the pedagogical object was made visible. Her findings indicated that an evaluative episode can serve as an analytical space in which the dynamism of an activity system is momentarily frozen, enabling one to model human activity in the system under investigation and, accordingly in her study, to understand pedagogy in context. By using grounded theory, theoretical and methodological approaches, Huang and Lin (2013) showed a way to address complexity in the activity of learning and its development based on recognition of central cultural factors in mathematics teaching/learning. Their analysis through this systematic network revealed the factors that influenced Atayal students' learning of mathematics under their cultural background.

Remarkably, Huang and Lin (2013) found that tension between Atayal culture's speech representation system and Chinese culture's literal representation system caused Atayal students' difficulties in carrying out the transformation of representations. And that, the tension formed between Atayal students' holistic thinking style and the analytic thinking style presented in teaching material and teaching activities had been unfavorable to their understanding of mathematical concepts. According to Huang and Lin, their analysis structure of the classroom activity and the design of teaching activities developed from a sociocultural orientation and activity theory indeed improved Atayal students' mathematical learning within the cultural stream. Having analyzed data within an interpretive paradigm, Naidoo (2017) found that each master teacher modeled their classrooms as individual activity systems and the teaching and learning of mathematics was completed as a dynamic activity.

Further, Naidoo (2017) exhibited that the use of visuals as tools within the different activity systems made the abstract nature of certain mathematics concepts more concrete. And that, the high level of student engagement and interaction in the different activity systems seemed to indicate that through the use of activity theory the teaching and learning of mathematics was more effective. However, Naidoo (2017) summarized all these activity systems into one general activity system, without even any examples in text, making it too hard to conceptualize what rules worked in which activity system and how the division of labor was handled in each. Trust (2017) found that the object-oriented action of finding new knowledge was influenced by a network of elements in the Math Subject Community activity system that interacted with and mutually constituted one another. In the meantime, Zevenbergen and Lerman (2007) found a very low rating on aspects of pedagogy related to intellectual quality. Outstandingly, they noted that the use of IWBs actually reduced the quality of mathematical learning opportunities, provided fewer opportunities for connecting to the world beyond schools, and offered little independent learning opportunities for students.

Further, through classroom observations, Zevenbergen and Lerman (2007) revealed that overall pedagogy remained similar to traditional modes of teaching. And that, the depth of questioning also remained at a relatively superficial level where low levels of questions were posed. Thus, they observed that there remained considerable tension in 
what was offered and what could have been asked. They, then, theorized that the key tension appeared to be between the artifact (IWBs) and the division of labor, and thus, the teachers' control of the class and at the same time the artifact (IWBs) militated against any pedagogical shift towards greater intellectual change. However, in this study, arguments were focused on IWBs, their affordances, and constraints rather than how IWBs mediate learning in terms of the elements of CHAT. Little or no attention was given to IWBs as a mediating tool in identifying the participants and resources present in the classroom as an activity system, and their different roles and responsibilities. Hence, such findings were not surprising. Overall, all studies, apart from Zevenbergen and Lerman's, had positive findings in terms of pedagogical transformation in the teaching and learning of mathematics.

\section{Implications to teachers in Uganda}

By drawing on CHAT as an analytical framework, the reviewed studies have provided an understanding of how emerging technologies can mediate teaching and learning in a mathematics classroom. However, what can Ugandan mathematics teachers learn from this literature? What does it tell us about how mathematics teachers create the conditions for effective teaching and learning of mathematics? Although from this review, there is no ultimate formula that has elucidated how to do this, the nature of conditions that contribute to enhancing students' learning through the use of technology in mathematics has been noted from the literature. I have organized these features according to two interconnected and shared happenings namely active student engagement in the teaching and learning process and creating collaboration spaces for dialogue and interaction between the students and the teacher.

One way of engaging students in shared learning experiences is through the use of emerging technologies, which have the potential of bringing about transformative learning. However, active student engagement in the teaching and learning process is swayed by a complex collection of aspects, many of which are decided, in the first case, by the pedagogical affordances and constraints within the participation rights and responsibilities ascertained in the process. These, in the lens of CHAT, are manifested as community, rules, and division of labor. That is why it is very important for teachers to plan in order to set out the rules for each mathematics lesson, the responsibilities of each subject involved and the community involved in the context of what is being taught at the time. As demonstrated by literature, pedagogy that is focused solely on receipt of correct answers and solutions does not strike at the core of what mathematics learning strictly requires. Consequently, teachers should always endeavor to create a classroom context that supports students' increasing cognizance of themselves as legitimate contributors in the construction of mathematical knowledge.

In a setting where ideas are shared, students' own ideas become resources for their own learning and further still, their explanations inspire, challenge, and widen other students' mathematical thinking. Thus, an effective teacher is one who creates collaboration spaces for dialogue and interaction between the students themselves and the teacher and the students. Particularly, the opportunity for learning is influenced by what students are helped to co-produce through dialogue. Such dialogue can be supported if a teacher takes the time to analyze their lesson planning through the CHAT lens. This means that a teacher should take their time in identifying what the 
subject, object, tool, outcome, rules, community, and division of labor of their lessons should be or look like. Take an example of Zevenbergen and Lerman (2007) who did not clearly define the subject, object, outcome, rules, community, and division of labor of their activity system. It became hard, even for them, to trace the inter-links in their activity system, and hence, their negative finding to the effect that the overall pedagogy remained similar to traditional modes of teaching was not surprising.

Therefore, teachers should work towards establishing classroom spaces that are conducive to sharing, and at developing inter-relationships that create physical spaces for students to actively engage in the teaching and learning process. That way, students will develop their mathematical individualities, thus achieving both relational understanding and highly scores on assessment. Generally speaking, having identified the object of their lessons, teachers should note that the subject of their classroom activities or programs belongs to a community that is governed and mediated by rules and division of labor. And that, members of the community have to collaborate with each other to achieve the outcome of each activity system, which is the teaching and learning of mathematics.

\section{Conclusion}

From this review of literature, I acutely note four concerns regarding CHAT. First, CHAT is based on the assumption that all human actions are mediated by tools and cannot be separated from the social ambiance in which action is carried out. Thus, it provides a set of assumptions by which to understand and explain learning processes that occur in say, a mathematics classroom. Second, it is clear that every classroom can function as an activity system and each member of the classroom community can serve a specific purpose. And that, all role players can work in collaboration with the facilitator to achieve the outcome of the activity. However, in order for this outcome to be achieved, rules should be followed and specific instruments should be used. Third, activity systems are dynamic and subject to change. However, when a teacher wants to carry out action research, they could do as Hardman (2007) did. She briefly froze the dynamic system so as to focus an analytical lens on the object of the system. Fourth, CHAT brings to the fore contradictions and tensions that exist within and between activity systems.

Although such contradictions generate disturbances and conflicts, they are also the primary sources of change and expansive developments, hence providing innovative attempts to change the activity system. Thus, teachers should be aware that tools can limit as well as enable social interaction, so must be applied wisely and appropriately to promote the most effective learning. Further, tools like emerging technologies should be aligned with the intended goals and objectives of learning. Of import to note, there is no agreed methodology for the utilization of CHAT. Researchers are always presented with many decisions as the ensuing instant step in the operationalization of the activity system's components. Thus, reviewing how the research community has previously operationalized these components to the mathematics classroom may help to step forward the many decisions the researcher needs to make.

Although CHAT has proved to have immense value in understanding how emerging technologies can mediate teaching and learning mathematics, it has not been fully explored in the context of teaching and learning mathematics. It is evidenced by this 
review of literature that scholarly articles that have employed CHAT as their theoretical or analytical frameworks are too few and yet still, the few that have utilized it have not exploited its maximum potential. Ultimately, CHAT and Activity Theory have been used synonymously. Whether using Activity Theory or CHAT, the focus in literature has been on defining the subject, object, tools, outcome, rules, community, and division of labor of the activity system. This leaves one wondering the difference between the Activity Theory and CHAT in terms of the researchers' conceptualization of the same in the reviewed studies. Globally, this review serves as a wakeup call for the utilization of CHAT in its full potential and contextually, CHAT would serve as a good starting point for mediating emerging technologies and the teaching and learning in Ugandan mathematics classrooms.

\section{Abbreviations}

AT: Activity Theory; CHAT: Cultural Historical Activity Theory; ETs: Emerging technologies; ICT: Information and Communication Technology; IWBs: Interactive whiteboards; KZN: KwaZulu-Natal; TEFA: Technology-Enhanced Formative Assessment; TLT: Teacher Learning of TEFA; UACE: Uganda Advanced Certificate of Education; UCE: Uganda Certificate of Education; UNEB: Uganda National Examinations Board; ZPD: Zone of Proximal development

\section{Acknowledgements}

Sincere appreciation goes out to the Carnegie/Mellon Scholarship Fund that sponsored the author to pursue a Post Graduate Diploma in Education Technology at University of Cape Town, South Africa, from where the notion of CHAT and emerging technologies emerged.

\section{Author's contributions}

The entire article has been prepared by the sole author, who read and approved the final manuscript.

\section{Funding}

Not applicable

\section{Availability of data and materials}

Not applicable

\section{Competing interests}

The author declares that she has no competing interests.

Received: 30 April 2019 Accepted: 25 September 2019

Published online: 23 October 2019

\section{References}

Bakhurst, D. (2007). Vygotsky's demons. In H. Daniels, M. Cole, \& J. V. Wertsch (Eds.), The Cambridge companion to Vygotsky (pp. 50-76). New York: Cambridge University Press.

Batiibwe, M. S. K., Bakkabulindi, F. E. K., \& Mango, J. M. (2018). How do the constructs of the TPACK framework relate with the use of ICT in pedagogy among teachers of mathematical disciplines in universities in Uganda? African Journal of Education, Science and Technology, 5(1), 1-11.

Beatty, I. D., \& Feldman, A. (2012). Viewing teacher transformation through the lens of cultural-historical activity system. Education as Change, 16(2), 283-300.

Brown, C., \& Gachago, D. (2013). Emerging technologies in higher education. A guide for higher education practitioners. In Innovating Pedagogy 2016: Open University innovation report 5. Milton Keynes: The Open University.

Cole, M., \& Engeström, Y. (1993). A cultural historical approach to distributed cognition. In G. Salomon (Ed.), Distributed cognitions: Psychological and educational considerations (pp. 1-46). Cambridge: Cambridge University Press.

Engeström, Y. (1987). Learning by expanding: An activity-theoretical approach to developmental research. Helsinki: OrientaKonsultit http://lchc.ucsd.edu/MCA/Paper/Engestrom/expanding/toc.htm. Accessed 4 June 2018.

Engeström, Y. (2001). Expansive learning at work: Toward an activity theoretical reconceptualization. Journal of Education and Work, 14(1), 133-156. https://doi.org/10.1080/13639080020028747.

Engeström, Y. (2007). Enriching the theory of expansive learning: Lessons from journeys toward configuration. Mind, Culture, and Activity, 14(2), 23-39. https://doi.org/10.1080/10749030701307689.

Gough, D. (2007). Weight of evidence: A framework for the appraisal of the quality and relevance of evidence. Research Papers in Education, 22, 213-228.

Halawey, M. (2013). Emerging technology: What is it? Journal of Technology Management \& Innovation, 8(3), 108-115.

Hardman, J. (2007). An activity theory approach to surfacing the pedagogical object in a primary school mathematics classroom. Critical Social Studies, 1, 53-69.

Hardman, J. (2015). Pedagogical variation with computers in mathematics classrooms: A cultural historical activity theory analysis. Psychology in Society, 48, 47-76.

Huang, C. H., \& Lin, F. (2013). Using activity theory to model the Taiwan Atayal students' classroom mathematical activity. International Journal of Science and Mathematics Education, 11, 213-236.

Leont'ev, A. N. (1978). Activity, consciousness, and personality. Englewood-Cliffs: Prentice-Hall. 
Mishra, P., \& Koehler, M. J. (2006). Technological pedagogical content knowledge: A framework for teacher knowledge. Teachers College Record, 108(6), 1017-1054.

Naidoo, J. (2017). Exploring the use of activity theory as a framework for the teaching and learning of mathematics. Pythogoras, 33(1), 1-9.

Ng'ambi, D., Gachago, D., Ivala, E., Bozalek, V., \& Watters, K. (2014). Emerging technologies in South African Higher Education Institutions: Towards a teaching and learning practice https:/vula.uct.ac.za/access/content/group/8ff4f1d3-4a8 Accessed 18 Dec 2018.

Nussbaumer, D. (2012). An overview of cultural historical activity theory (CHAT) use in classroom research 2000 to 2009. Educational Review, 64(1), 37-55. https://doi.org/10.1080/00131911.2011.553947.

Roth, W. M. (2007). The ethico-moral nature of identity: Prolegomena to the development of third-generation culturalhistorical activity theory. International Journal of Educational Research, 46(2), 83-89. https://doi.org/10.1016/j.jer. 2007.07.008.

Rowe, M., Bozalek, V., \& Frantz, J. (2013). Using Google drive to facilitate a blended approach to authentic learning. British Journal of Educational Technology, 44, 594-606. https://doi.org/10.1111/bjet.12063.

Sharples, M., de Roock, R., Ferguson, R., Gaved, M., Herodotou, C., Koh, E., Kukulska-Hulme, A., Looi, C.-K., McAndrew, P., Rienties, B., Weller, M., \& Wong, L. H. (2016). Innovating pedagogy 2016: Open university innovation report 5. Milton Keynes: The Open University.

Siemens, G. (2005). Connectivism: A learning theory for the digital age. International Journal of Instructional Technology and Distance Learning, 2(10), 3-10.

Trust, T. (2017). Using cultural historical activity theory to examine how teachers seek and share knowledge in a peer-to-peer professional development network. Australasian Journal of Educational Technology, 33(1), 98-113.

Uganda National Examinations Board. (2005). Uganda certificate of education: Regulations and syllabuses 2005-2010. Kampala: Author.

Uganda National Examinations Board. (2012). Uganda advanced certificate of education: Regulations and syllabuses 2012-2017. Kampala: Author.

van Oers, B. (2001). Educational forms of initiation in mathematical culture. Educational Studies in Mathematics, 46(3), 59-85. https://doi.org/10.1023/A:1014031507535.

Veletsianos, G. (2011). Designing opportunities for transformation with emerging technologies. Educational Technology, 51(2), 41-46.

Veletsianos, G. (2016). The defining characteristics of emerging technologies and emerging practices in digital education. In Emergence and innovation in digital learning. https://doi.org/10.15215/aupress/9781771991490.01.

Vygotsky, L. S. (1978). Mind and society: The development of higher mental processes. Cambridge: Harvard University Press.

Zevenbergen, R., \& Lerman, S. (2007). Pedagogy and interactive whiteboards: Using an activity theory approach to understand tensions in practice. In J. Watson \& K. Beswick (Eds.), Mathematics: Essential research, essential practice, 2, Proceedings of the $30^{\text {th }}$ Annual conference of the Mathematics Education research Group of Australasia MERGA.

\section{Publisher's Note}

Springer Nature remains neutral with regard to jurisdictional claims in published maps and institutional affiliations.

\section{Submit your manuscript to a SpringerOpen ${ }^{\circ}$ journal and benefit from:}

- Convenient online submission

- Rigorous peer review

- Open access: articles freely available online

- High visibility within the field

- Retaining the copyright to your article

Submit your next manuscript at $\boldsymbol{\nabla}$ springeropen.com 